\section{Aclonowledgements}

The authors would like to thank the Eastern Health Board, Special Hospital Care Programme, who funded the project, and Ms Jean Gavin.

\section{References}

BROWN, H. R. (1987a) The impact of sulcide on theraplsts in training. Comprehenstue Psychiatry, 28, 101-112.

-(1987b) Patlent sulcide during reaidency training: incidence, implications and programme response. Joumal of Psychtatric Education, 11, 201-216.

ChrantoB, C. M., HAMADA, R. S., BAUER, G., KInNeY, B. \& TORIGOE, R. Y. (1988) Patients suicldes: frequency and impact on peychilatrists. American Joumal of Psychlatry. 146, 224-228.

HENN, R. F. (1978) Patient sulcide as part of poychlatric residency. American Joumal of Psychlatry. 138. 745746.

HOROWITZ, M., WLNER, N. \& ALVAREZ, W. (1979) Impact of Event Scale: a measure of subjective stress. Psychosomatic Medictine, 41, 209-218.
KAHNE, M. J. (1968) Sulclde among patients in mental hoopitals. A study of the poychlatrists who conducted their poychotherapy. Psychiatry. 3, 32-43.

LTMNN, R E. (1965) When patients commit sulcide. American Joumal of Psychotherapy. 4. 570-576.

NESS, D. E. \& PFErTER, C. R. (1990) Sequelae of bereavement resulting from sulcide. American Joumal of Psychlatry, 147, 279-285.

O'RenLY, R. L., TRUANT, G. S. \& DONALDSON, L. (1990) Psychlatrists' experience of suicide in their patients. Psychiatric Journal of the Universtty of Ottawa, 18, 173176.

Elizabeth M. J. Cryan, Consultant Psychiatrist, James Connolly Memorial Hospital, Blanchardstown, Co Dublin and Honorary Lecturer in Clinical Psychiatry, Royal College of Surgeons in Ireland; Paul Kelly, Tutor in Psychology, Untwerstty College, Dublin; and Brian McCaffrey, Consultant Psychiatrist, St Vincent's Hospital, Fairvtew, Dublin 3, Republic of Ireland

\title{
The emergency treatment of overdose: a problem of consent to treatment
}

\author{
Tim Hardie, Kamaldeep Bhui and Phillip Brown
}

We auvoyed 119 poychichtists to see how thoy would act with a patient who has taken a potentially lothal overdose, has no mental illness, and ts refueing treatment. There wos aubetantiled discoreement. There moy bo a risk of action under clvill low whether the poychictitis decides to treet the potient without his or her consent or not. The Low Commiseton are examining whether mental disorder, as defined in the Mental Heath Act 1983, should be used as a test of incopoclty to give consent to modiced treatiment. such lectalation would help doctors but moy encourage a wide interprefation of the definition of mental disorder.

Psychiatrists may be called to assess patients who are refusing treatment following an overdose. If the patient is not amenable to persuasion, the psychiatrist may be asked to decide whether treatment should be given without the patient's consent. If treatment is forctbly administered, then the doctor may expose himself to a suit for trespass, assault or battery. If the doctor chooses not to treat the patient, and the patient suffers as a result, he may be sued for negligence. The main defence in the former case will be that of 'necessity' and in the latter case it will be that of volenti non fit injuria', ie. that the patient voluntarlly assumed the risk of not giving consent for treatment (Korgaonkar \& Tribe, 1993). In a case of alleged negligence, breach of duty of care will be judged on the "expert opinion of medical witnesses giving their views on current modes of accepted practice" (NelsonJones \& Burton, 1990)

Although current practice regarding consent to medical treatment is governed by common law, the Law Commission are examining whether a test of incapacity to consent to 
medical treatment should be included in future statutory legislation (Law Commission, 1993). We hypothesised that psychiatrists would not agree on what was good practice because of lack of clear legislation and the conflict of interest between the patient's ctvil rights and a doctor's duty of care.

\section{The study}

The following vignette was sent to 119 psychiatrists in the South East Thames Region (57 consultants, 15 senior registrars, 19 registrars and 28 senior house officers).

"A 24-year-old woman is in Accident and Emergency. Two hours earlier she had taken an overdose of 100 paracetamol tablets. She was brought into A \& E by her parents and is currently refusing all treatment including stomach washout, emetics and blood tests, despite vigorous attempts to persuade her by her parents and all the staff involved. She is not attempting to leave. She is well known to the psychiatric services as she has taken 15 overdoses in the past, and been referred to the psychilatric services on each occasion. She was discharged from hospital ten days ago, having been on a psychiatric ward for two weeks. During the course of this admission and at all other times when seen by a psychiatrist there has been no evidence of affective disorder or psychotic illness. There is no current evidence of blological features of depression or psychotic symptoms."

The respondents were asked to chose their immediate management from one of four options.

(a) Continue to persuade her untll the last possible moment that a stomach washout is still likely to be of benefit and then physically restrain her and administer a stomach washout using sedation if necessary, taking all necessary precautions to ensure that the patient comes to no harm.

(b) Continue to persuade her untll four hours post-overdose (the usual time for checking paracetamol levels), and then physically restrain her and take a blood sample to see if she needs treatment. Then, if blood levels are within the toxic range, sedate if necessary and forclbly give all necessary treatment.

(c) Continue to persuade her untll she develops any signs of paracetamol toxicity, then forcibly administer antidote using sedation if necessary and giving antidote is still considered worthwhile.

(d) Give no treatment but continue to try to persuade her to have treatment.

Paracetamol would have a high chance of being fatal at this dose and would not be expected to affect mental state until many hours after ingestion, at which point the patient would be seriously medically ill. If the doctors wait until the patient is cognittvely impaired by the effects of the drug, before they disregard the patient's wishes, the patient may have liver failure and consequently a very poor prognosis (Harrison et al, 1990).

\section{Findings}

The response rate was $69 \%$. Of the respondents, 35\% chose option (a), 38\% chose option (b), 10\% chose option (c) and $17 \%$ chose option (d). The response rate was similar for all grades of doctors. There was no clear consensus as to the correct course of action, although most doctors chose to treat the patient at some point without her consent.

\section{Comment}

The problem appears to revolve around whether the patient has the "capacity to give or withhold consent to treatment". The Law Commission have suggested that, for people not to have the capacity for consent, they should at least suffer from a mental disorder as currently defined in the Mental Health Act 1983. However, referring to the judgment of Lord Donaldson M.R. In $\operatorname{Re} T$ (1992), they recommend a wide interpretation of the definition to include "the temporary effects of shock or an injury". Shock in this instance being mental shock. Lord Donaldson also stated that she "must have been anxious as to the health of her baby", and that this was one of the factors which contributed to her mental condition. It is possible, in the light of Lord Donaldson's judgment and the Law Commission's recommendations, that individuals who have severe emotional upset for any reason should be considered as potentlally having impaired capacity to give consent. For the patient in the vignette, if there had been evidence of recent interpersonal or legal difficulties, then this may be considered sufficient if they caused her to be emotionally upset. 
Lord Donaldson also stated that: "The more serious the decision, the greater the capacity required." With the patient in the vignette, treatment is potentially life saving, and therefore the patient should have maximum mental capacity before her wish not to have treatment be respected.

It seems likely that if mental capacity is 'tled' to mental disorder in the way that the Law Commission are recommending, that psychiatrists will be involved in more cases where medical treatment is being refused. The responses to the vignette suggest that psychiatric opinion is currently divided about the correct course of action, and this may provide fertile ground for a major ctvil action. It would be good practice for doctors to consult with colleagues before embariding on any treatment without the patient's consent and to make accurate contemporaneous records of how any decision was arrtved at, who made the decision and on what basis the decision was made. In these circumstances, doctors should also consider making an application to the High Court for a declaration that to carry out the proposed treatment would be lawful. If the recommendations of the Law Commission become statute, then the risk of litigation may be reduced, but doctors will be encouraged to make a wide interpretation of the meaning of mental disorder.

\section{Aclonowiedgements}

We are grateful to Professor Elaine Murphy, Dr J. P. Barker and to Ms Debble Pritchard.

\section{Reference:}

HARRISON, P. M., O'GRADY, J. G., KEAYS, R. T., ALEXANDER, G. J. M. \& Wunus, R. (1990) Sertal prothrombin time as prognostic indicator in paracetamol induced fulminant hepatic fallure. Brttish Medical Joumal, S01. 964-966.

Korghonrar, G. TRaBe, D. (1993) Sulcide and attempted suiclde - a doctor's llability. Brttsh Joumal of Hospittal Medictre, 80, 680-681.

LAw Comanssion (1993) Consultation Paper No 129: Mentally Incapacttated Actults and Dectsion-Maktng. Medical Treatment and Research pp10-24. London: HMSO. LORD DONuLDson Or LMmNGTON M. R. (1992) In Re T. (Adult Refusal of Treatment). Weekly Law Reports, 3, 782-805. NERSONJONEs, R. \& BURTON, F. (1990) Medical Negligence Case Law, p.8 Fourmat Publishing.

Tim Hardie, Research Fellow, UDMS, Guy's Campus, St Thomas' Street, London, SE1 9RT, Kamaldeep Bhui, Senior Registrar, Maudsley Hospital, London SE5 8AZ; and Phillip Brown, Senior Registrar in Adult Forensic Mental Health Services,

Manchester M25 9BL

Prestwich Hospital

-Correspondence 